Wright State University

CORE Scholar

\title{
The Snail Darter and the Dam: How Pork-Barrel Politics Endangered a Little Fish and Killed a River
}

Drew A. Swanson

Wright State University - Main Campus, drew.swanson@wright.edu

Follow this and additional works at: https://corescholar.libraries.wright.edu/history

Part of the History Commons

\section{Repository Citation}

Swanson, D. A. (2014). The Snail Darter and the Dam: How Pork-Barrel Politics Endangered a Little Fish and Killed a River. H-Environment, H-Net Reviews.

https://corescholar.libraries.wright.edu/history/252

This Book Review is brought to you for free and open access by the History at CORE Scholar. It has been accepted for inclusion in History Faculty Publications by an authorized administrator of CORE Scholar. For more information, please contact library-corescholar@wright.edu. 


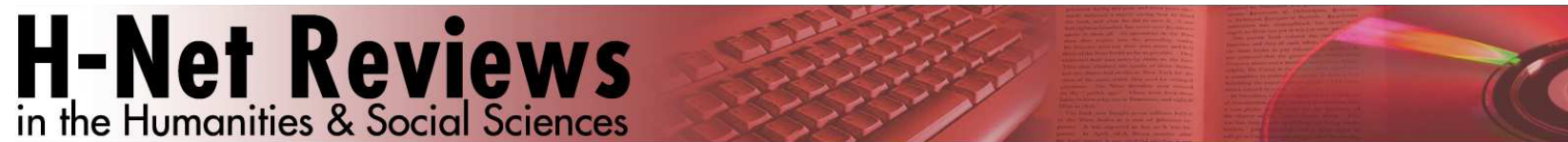

Zygmunt J. B. Plater. The Snail Darter and the Dam: How Pork-Barrel Politics Endangered a Little Fish and Killed a River. New Haven: Yale University Press, 2013. xvi + 369 pp. \$35.00 (cloth), ISBN 978-0-300-17324-6; \$25.00 (paper), ISBN 978-0-300-20941-9.

Reviewed by Drew A. Swanson

Published on H-Environment (August, 2014)

Commissioned by David T. Benac

The last year has seen a wave of thoughtful scholarship on the multiple impetuses for one of the United States' most powerful social movements: environmentalism. A recent slate of excellent books on the various branches of environmental activism include Paul Sabin's The Bet: Paul Ehrlich, fulian Simon, and Our Gamble over Earth's Future (2013), Adam Rome's The Genius of Earth Day: How a 1970 Teach-In Unexpectedly Made the First Green Generation (2013), Jacob Hamblin's Arming Mother Nature: The Birth of Catastrophic Environmentalism (2013); Brian Drake's Loving Nature, Fearing the State: Environmentalism and Antigovernment Politics before Reagan (2013); and Frank Zelko's Make It a Green Peace: The Rise of Countercultural Environmentalism (2013). Legal scholar Zygmunt J. B. Plater's new book, The Snail Darter and the Dam: How Pork-Barrel Politics Endangered a Little Fish and Killed a River, differs from these historiesit is both more personal and less interested in exploring the connections between a particular environmental moment and the movement's larger history-yet it is an important complement to this blossoming scholarship.

Plater has a close relationship with the legal case at the heart of this book-Tennessee Valley Authority (TVA) $v$. Hiram Hill et. al (1978)-serving as the chief legal counsel opposing the TVA. Plater has written legal articles on the case in the past, but in this book provides a much more detailed and engaging account of one of the nation's most important environmental law cases. As the first Supreme Court case testing the Endangered Species Act (ESA) of 1973, TVA vs. Hill explored the nation's new commitment to conserving imperiled species and their habitats, and while the case asserted the ESA's legal teeth, the ultimate results revealed that the underlying sociopolitical support for a firm ESA was less solid.

The Snail Darter and the Dam is a chronological narrative, beginning with brief histories of the Little Tennessee River valley and the TVA, which by 1960 had plans to build a dam it would call the Tellico near the river's mouth. Local dam opponents fought the project on a number of grounds, arguing for alternative development schemes and the preservation of agricultural lands and existing fishing interests, pointing out the injustice of land seizure for economic speculation under eminent domain, emphasizing the historical and religious significance of the land to be inundated by the dam (which included both Cherokee and Euro-American colonial sites), and noting the questionable economic benefits of the Tellico project. These legal challenges proved unable to disrupt TVA's plans, but in 1974 the fight against Tellico shifted with the discovery of a tiny endangered perchsoon named the snail darter-in the Little Tennessee; the ESA, passed the previous year, declared that public projects must not threaten to harm species facing possible extinction. Plater describes in detail the legal wrangling that followed, culminating in the Supreme Court case and a victory for dam opponents. The book explains, however, that the case was only the midpoint in the darter versus dam story, as sordid political negotiations followed, resulting in the establishment of a congressional "God committee," charged with weighing the costs and benefits of federal projects that might result in the extinction of a species. In this committee, the darter and its defendants won again, but a congressional appropriations rider exempting Tellico from the ESA followed, and the fight against the dam finally ended in 1979 when President Jimmy Carter refused to veto the bill.

Plater's narrative offers several insights into both the case and 1970s environmentalism. First, the book highlights the immense complexity of these legal and political battles, walking readers through the grinding work of contacting representatives, building support networks of activists, researching cases, and filing briefs; The Snail Darter and the Dam moves much of this hidden labor out of the shadows. Second, Plater's experience demonstrates the shoestring nature of many environmental or- 
ganizations at the time. Often operating out of attics or cramped rental offices and subsisting on savings and donations from a few dedicated backers, these groups still found ways to influence the political process, and environmental historians would do well to follow Plater's lead and pay more attention to lobbyists. Finally, the author argues for the immense importance of the media in framing environmental issues and swaying public opinion. For TVA vs. Hill, Plater is convinced that the national media's "avoidance of complex thinking" reflected "a low opinion, apparently shared by many within Washington, of the intellectual ability and interest of the American populace" (p. 176). Once newspapers and television news defined the case as a tiny fish versus an enormous dam project, the popular case was already all but doomed.

The Snail Darter and the Dam is an unconventional history in many regards. While Plater is quick to declare that this is "not a memoir," it is perhaps most useful to environmental historians as such, portraying at least one experience on the frontlines of legal action during a formative period in the American environmental movement (p. xiv). The book is short on footnotes and draws heavily on Plater's memory, notes, and reconstructions of conversations and events now more than thirty years in the past, but the book does provide a link to an online doc- uments repository (hosted by Plater's home institution, Boston College) that contains extensive primary sources which undergird the narrative. In places the book is quite impressionistic, as Plater speculates on what motivated other people, but in others it is rich in detail, as when providing the most thorough description to date of the Supreme Court arguments. Where the book is least effective is in supporting Plater's argument that the snail darter was more than just a tool of opportunity for dam opponents. He asserts that he and other supporters of the darter were not "hypocrites as well as fools, environmental extremists manipulating the darter to misuse the law over a technicality," and yet throughout the book Plater admits to questioning their motives and their implications (p. 43). The issue is both troubling and refreshing for Plater's honesty.

Overall, Plater admirably accomplishes his primary objective, to provide an accessible history of an important episode of environmental law from the environmentalists' perspective. More primary source than objective history, The Snail Darter and the Dam is nonetheless an invaluable read for legal scholars, environmental historians, and students of the messy realities of American environmental politics.

If there is additional discussion of this review, you may access it through the list discussion logs at:

http://h-net.msu.edu/cgi-bin/logbrowse.pl.

Citation: Drew A. Swanson. Review of Plater, Zygmunt J. B., The Snail Darter and the Dam: How Pork-Barrel Politics Endangered a Little Fish and Killed a River. H-Environment, H-Net Reviews. August, 2014.

URL: http://www.h-net.org/reviews/showrev.php?id=42146

This work is licensed under a Creative Commons Attribution-NoncommercialNo Derivative Works 3.0 United States License. 